\title{
Metal Ions Impact on Shewanella Oneidensis MR-1 Adhesion to ITO Electrode and the Enhancement of Current Output
}

\author{
Aisha Alshahrani1,2*, Alanah Fitch ${ }^{1}$, John Al-Bazi ${ }^{3}$ \\ ${ }^{1}$ Department of Chemistry and Biochemistry, Loyola University Chicago, Chicago, IL, USA \\ ${ }^{2}$ Department of Chemistry, Al Baha University, Al Baha, KSA \\ ${ }^{3}$ Department of Chemistry, Northeastern Illinois University, Chicago, IL, USA \\ Email: *aalshahrani@luc.edu
}

How to cite this paper: Alshahrani, A., Fitch, A. and Al-Bazi, J. (2019) Metal Ions Impact on Shewanella Oneidensis MR-1 Adhesion to ITO Electrode and the Enhancement of Current Output. American Journal of Analytical Chemistry, 10, 428-443. https://doi.org/10.4236/ajac.2019.109031

Received: August 29, 2019

Accepted: September 20, 2019

Published: September 23, 2019

Copyright $\odot 2019$ by author(s) and Scientific Research Publishing Inc. This work is licensed under the Creative Commons Attribution International License (CC BY 4.0).

http://creativecommons.org/licenses/by/4.0/

\begin{abstract}
The goal of this study is to enhance the efficiency of bacterial extracellular electron transfer (EET) in Shewanella oneidensis MR-1 by enhancing adhesion to the electrode surface. Our results clearly show a major difference in attachment and behavior of $S$. oneidensis MR-1 for $\mathrm{Ca}^{2+}, \mathrm{Pb}^{2+}, \mathrm{Cd}^{2+}$, and $\mathrm{Mg}^{2+}$ compared to the control. The final microbial coverage, as measured by confocal microscopy and cathodic peak charge in cyclic voltammetry $\left(Q_{p c}\right)$, increases with increasing metal ion concentrations. We found the cells attached to the electrode increased more with the addition of metal ion concentrations in the following order of metals: $\mathrm{Ca}^{2+}>\mathrm{Pb}^{2+}>\mathrm{Cd}^{2+}>\mathrm{Mg}^{2+}$ compared to the control. The effect of metal ions on metabolism of the bacteria was tested by the riboflavin production and glucose consumption. Metabolic activity mirrored the same order of the activity as the electrochemical results.
\end{abstract}

\section{Keywords}

Shewanella oneidensis MR-1, Metal Ions, Extracellular Electron Transfer, Glucose, Riboflavin, Adhesion

\section{Introduction}

An interesting field of science and technology is microbial fuel cells (MFC). MFC use bacteria as the catalysts to convert the chemical energy of fuel (such as organic compounds) to electrical energy [1] [2]. MFCs have limitations of power output. This affects the various uses of MFC (electricity generation, wastewater treatment, biosensor, and hydrogen production) [3]. Efficiencies of MFCs are affected by cell 
configuration, electrode materials, electrolyte compositions, microorganisms, nutritional substrates [4], and the presence or absence of oxygen [5] [6].

Different mechanisms for electron transfer from the microbe to the electrode surface have been proposed. Direct electron transfer can be via either direct contact between outer membrane cytochromes (MtrC and OmcA) with electrodes or through extracellular conductive connections called bacterial nanowires [7] [8]. Mediated electron transfer via soluble redox mediators (such as flavin and riboflavin) also carries charge to the electrode [9] [10].

The effect of added ions to the solution is still not fully understood. Metal ions such as $\mathrm{Cu}^{2+}, \mathrm{Cd}^{2+}$, and $\mathrm{Fe}^{3+}$ have been studied to affect in enhancing MFC activity [11]. Wu et al. [12] showed that $10 \mathrm{mM} \mathrm{Fe}^{3+}$ addition to solution in $S$. oneidensis MR-1 increased the power output of MFCs by 1.1 times than control. Kim et al. [13] found that the addition of $100 \mathrm{mM} \mathrm{Fe}^{3+}$ in solution increased the power output of MFCs $80 \%$. Fitzgerald et al. [14] reported that the addition of $\mathrm{Ca}^{2+}$ at the concentration of $1.4 \mathrm{mM}$ increased the current density by more than $80 \%$ in $S$. oneidensis MR-1. Heavy metals, too, can increase power output. As an example, $\mathrm{Xu}$ et al. [11] found that the addition of 5-6 $\mathrm{nM} \mathrm{Cu}^{2+}$ and $\mathrm{Cd}^{2+}$ increased the power output of MFCs by $1.3-1.6$ times.

One possibility is that metal ions affect solution properties. It is known that metal ions increase the conductivity of electrolytes, decrease internal resistance, and can increase the power output of MFCs [15]. Electrolyte salt concentration correlated with ionic strength has been shown to affect power output [4] [16] [17].

In our research, we utilize $S$. oneidensis MR-1. $S$. oneidensis MR-1 is a gram-negative cell that contains three layers: the cytoplasmic membrane (CM) or inner membrane, the peptidoglycan layer which is external to the cytoplasmic membrane, and the outer membrane (OM) which is lipopolysaccharide-rich. The outer membrane $(\mathrm{OM})$ consists of the bilayer that composed lipid, protein, and lipopolysaccharide [18]. The extracellular polysaccharides (EPS) play a major role in mediating the bacterial colonization of surfaces and cell adhesion [19]. Metal ions bind to EPS and can affect the EPS structure, which affects adhesion. $\mathrm{Ca}^{2+}$ is important as an ionic cross-bridging molecule for negativelycharged polysaccharides [20] [21]. It has been suggested that negatively charged groups in the $\mathrm{O}$-antigen are able to mediate $\mathrm{Ca}^{2+}$ dependent cell adhesion as well [22]. $\mathrm{Ca}^{2+}$ and $\mathrm{Mg}^{2+}$ can affect bacterial adhesion and biofilm formation by impacting electrostatic interactions and physiology-dependent attachment processes [23].

The presence of metal ions in solution passively increases bacterial attachment to soil surfaces [24]. There it was suggested that salt non-specifically compresses of the double layer between negatively charged solid surfaces and negatively charged bacterial surfaces. The literature shows that salt affects bacterial adhesion to Teflon, glass, metal surface wettability, and metal oxide surface by increasing the ionic strength [25]. As an ion compresses the double layer, it might affect the microbes approach an electrode and attach to the surface [26]. 
The enhancement of microbially driven electrochemistry enhancement by metal ions may be offset by toxic biological effects tend to bind to a sulfhydryl group inside the cell [27]. In plants, they can affect photosynthesis, gaseous exchange, and nutrient absorption of plants [28].

The goal of this study is to study whether metal ions enhance the efficiency of bacterial extracellular electron transfer (EET) in $S$. oneidensis MR-1 by enhancing adhesion to the electrode for improving the current output of microbial fuel cells. We use Indium Tin Oxide (ITO) electrode surface to study microbial adhesion because it is a metal oxide [29]. Bacteria are known to attach on natural metal oxides [30]. Adhesion of bacteria and that subsequent effect on electrochemical behavior is studied by variation of metal ions such as $\mathrm{Ca}^{2+}, \mathrm{Pb}^{2+}, \mathrm{Cd}^{2+}$, and $\mathrm{Mg}^{2+}$ and their concentrations.

\section{Materials and Methods}

\subsection{Bacteria and Culture Condition}

Pellets of $S$. oneidensis MR-1bacteria were obtained from frozen $-80^{\circ} \mathrm{C}$ stock [29]. Triplicate samples were obtained from pellets harvested from frozen stock solutions with different concentrations of $\mathrm{MgCl}_{2}, \mathrm{CdCl}_{2}, \mathrm{PbCl}_{2}$, and $\mathrm{CaCl}_{2}$ (50, $100,200,400,600$, and $800 \mu \mathrm{M})$. Triplicates were maintained in an ice bath prior to subsequent electrochemical.

\subsection{Electrochemical Cell Setup and Measurements}

The electrochemical cell uses a $4.5 \times 1 \mathrm{~cm}^{2}$ electrochemical area indium tin oxide glass slide (ITO) as the working electrode. The reference electrode (RE) was an $\mathrm{Ag} / \mathrm{AgCl}$. The platinum wire counter electrode (CE) runs parallel to the ITO surface. This electrochemical cell holds $11 \mathrm{~mL}$ of the solution. The ITO glass slide was cleaned with isopropyl alcohol before use [31]. The slide was installed into the electrochemical cell and the microbial sample was pumped in by the Tygon tubes. The pump was stopped after the cell was filled with the microbial sample. The incoming and outgoing Tygon tubes were clamped shut. $+0.2 \mathrm{~V}$ vs $\mathrm{Ag} / \mathrm{AgCl}$ was applied during a two-hour growth and attachment period with continuous current sampling at one-minute intervals [29]. After the two-hour period, six sequential cyclic voltammograms $(\mathrm{CV})$ were obtained. The $\mathrm{CV}$ consisted of an initial negative-going potential scan at a rate of $5 \mathrm{mV} / \mathrm{s}$ applied between initial potential $\mathrm{E}_{\mathrm{i}}+0.2$ and switching potential $\mathrm{E}_{\mathrm{sw}}-0.5 \mathrm{~V}$ vs $\mathrm{Ag} / \mathrm{AgCl}$.

\subsection{HPLC analysis of riboflavin and glucose}

The culture suspensions were removed from the electrochemical cell after the 6 CVs of each experiment. The total amount was centrifuged.

For the analysis of riboflavin changes from the literature [11] were made. $5 \mu \mathrm{L}$ injected to HPLC. The HPLC was equipped with a UV detector and a C18 analytical column $(3 \mu \mathrm{m}, 150 \mathrm{~mm} \times 4.6 \mathrm{~mm}$ i.d. $)$. The injection volume consisted of water and $50 \%$ acetonitrile with a flow rate of $1.0 \mathrm{~mL} \cdot \mathrm{min}^{-1}$. The HPLC profile 
was monitored at $266 \mathrm{~nm}$.

Glucose consumption was analyzed by the HPLC/PMP derivatization method of Zhang et al. [32].

\subsection{Olympus Microscope Imaging Procedure}

After the experiment, the ITO slide was removed from the electrochemical cell and air dried. Then, it was imaged with a microscope using confocal microscopy.

\subsection{Scanning Electron Microscopy (SEM) Analysis}

Post experiment, the ITO electrode was removed from the electrochemical cell and fixed with $2.5 \%$ glutaraldehyde for two hours. Fixed cells were washed three times with phosphate buffer ( $\mathrm{pH} 7.0,50 \mathrm{mM})$, dehydrated by alcoholic series $(60 \%, 70 \%, 80 \%, 90 \%, 95 \%$, and $100 \%)$, and then air dried. It was imaged using an SEM (HITACHI, SU3500) [33].

\section{Results and Discussion}

Bacteria samples were injected into the electrochemical cell for a two-hour anodic loading period at the potential of $+0.2 \mathrm{~V}$ vs. $\mathrm{Ag} / \mathrm{AgCl}$. The net current density was monitored during the loading process. Figure 1(a), shows a typical loading current density vs. time with blanks (no bacteria) tryptic soy broth (TSB) only, TSB with metal added, control (TSB with bacteria), and $\mathrm{Cd}^{2+}$ ion addition. Addition of new food source, as anticipated, allowed proliferation of the bacteria, Figure 1(b).

Figure 1(a) shows measurable features related to attachment. A rapid decay of current (Figure 1(a), feature 1) is associated with surface charging. This occurs within the first five seconds. Feature 2 (lag phase of time $\left(t_{\text {lag }}\right)$ with a nearly constant lag current $\left.\left(i_{\text {lag }}\right)\right)$ has been observed elsewhere. This start-up phase depends on substrate (i.e. glucose vs acetate), electron acceptor (fumarate, $\mathrm{Fe}^{3+}, \mathrm{O}_{2}$ ), and ionic strength [34]. For example, to reduce the start-up time Zhang et al. [35] used a glass fiber separator in MFC, as it has a low oxygen transfer coefficient and a low charge transfer resistances. Zou et al. [36] reported a much faster start-up rate for polymerized riboflavin (RF) onto carbon cloth (CC) electrode. Feature 3 is the maximum anodic loading currents density that occurs after the lag period grows. Feature 3 is followed by a decrease in current production. The drop can be altered by the addition of food source, Figure 1(b).

Figure 2 shows the effect of addition of metal ions $\mathrm{Mg}^{2}, \mathrm{Cd}^{2+}, \mathrm{Pb}^{2+}$, and $\mathrm{Ca}^{2+}$ on start-up time and maximum loading current density compared to the control. It can be observed that both the concentration of metal ion and the species of the metal ion are important factors in altering the electrochemical behavior. An increase in the metal ion concentration decreased the start-up time and increased maximum loading current density. The type of ion also had a significant impact on start-up time and maximum loading current density compared to the control. 


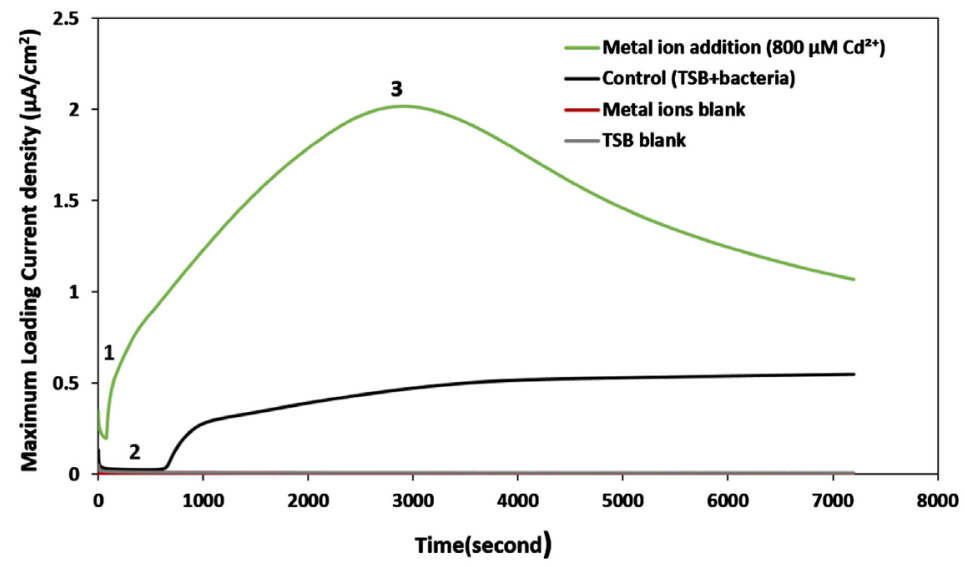

(a)

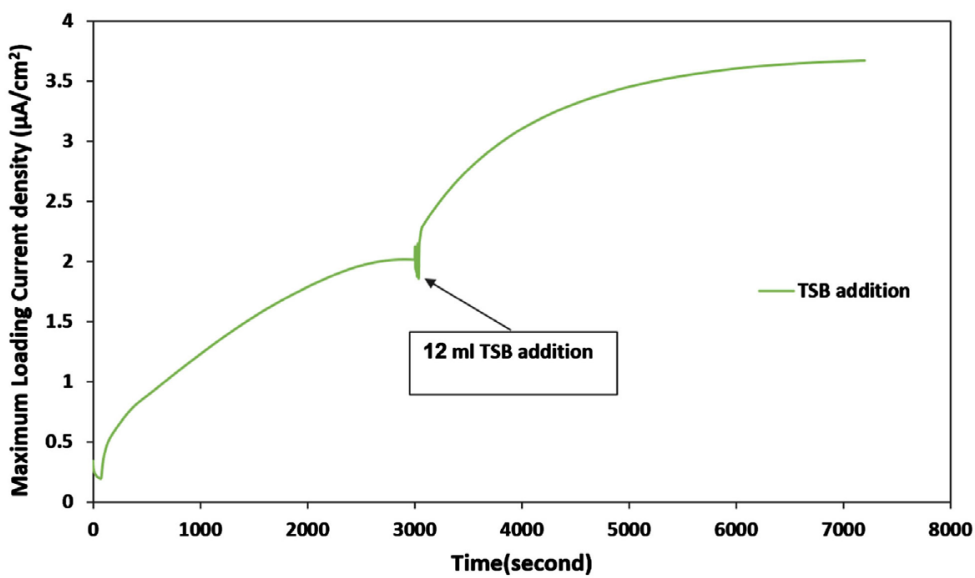

(b)

Figure 1. A typical loading current density vs. time. (a): the gray (TSB only) and red (TSB with metal ion added) lines are for blanks. The black line is for the control (TSB with bacteria). The green line is for $\mathrm{Cd}^{2+}$ addition. (b): $\mathrm{Cd}^{2+}$ experiment with an addition of 12 $\mathrm{ml}$ of TSB.

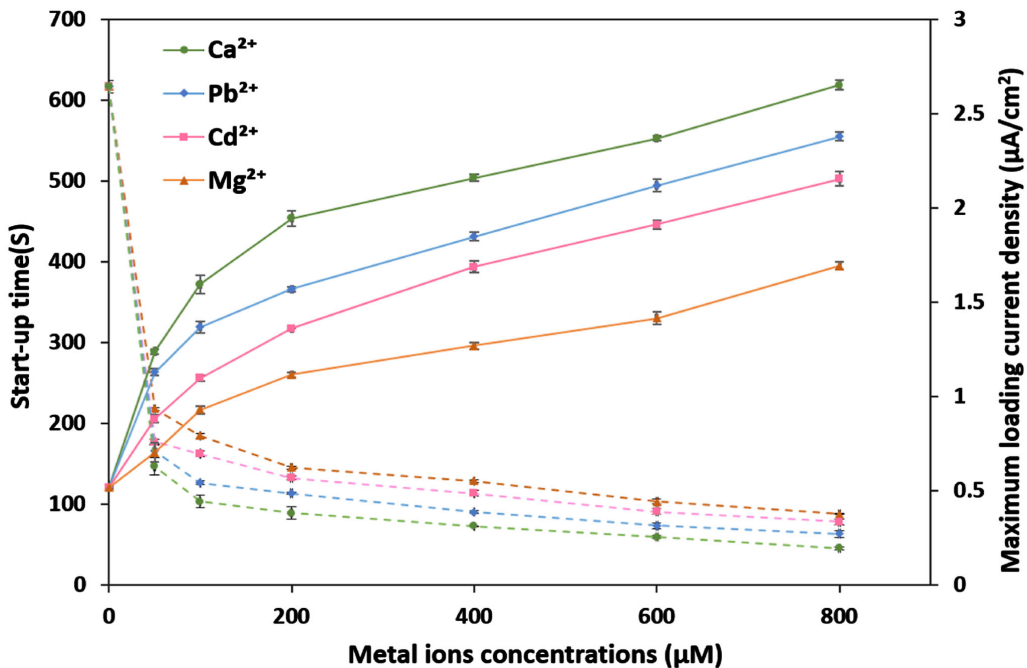

Figure 2. Start-up time (dashed line) and maximum loading current density (solid lines) vs. metal ion concentrations of $\mathrm{Mg}^{2+}, \mathrm{Cd}^{2+}, \mathrm{Pb}^{2+}$, and $\mathrm{Ca}^{2+}$ for $S$. oneidensis MR-1. 
The data show decreased start-up time consistent with literature experiments [34] [35] [36]. Here an increase in the metal ion concentration decreased the start-up time. This may be related to adhesion. Bacterial adhesion to the ITO electrode was observed by the scanning electron microscope (SEM) (Figure 3). Figure 3(a) the control (TSB + Bacteria) shows that few bacteria are attached to the electrode surface in the presence of growth media only. In contrast, the addition of $\mathrm{Mg}^{2+}, \mathrm{Cd}^{2+}, \mathrm{Pb}^{2+}$, and $\mathrm{Ca}^{2+}$ ions at $800 \mu \mathrm{M}$ increased the bacterial attachment to the surface of the electrode Figures $3(\mathrm{~b})-(\mathrm{e})$.

Confocal microscopy was used to measure percentage surface covered by $S$. oneidensis MR-1. ITO surface coverage was significantly enhanced by the addition of metal ions $\mathrm{Mg}^{2+}, \mathrm{Cd}^{2+}, \mathrm{Pb}^{2+}$, and $\mathrm{Ca}^{2+}$ compared to the control. The control resulted in a total of $10 \%$ surface area coverage. The surface area coverage increased over the control to approximately $51.6 \%$ for $\mathrm{Mg}^{2+}, 64.7 \%$ for $\mathrm{Cd}^{2+}$, $70.2 \%$ for $\mathrm{Pb}^{2+}$, and $78.5 \%$ for $\mathrm{Ca}^{2+}$ at ion concentration of $800 \mu \mathrm{M}$.

There is a direct relationship between maximum loading current density and bacterial coverage at the electrode surface (Figure 1(a), Feature 3). Figure 4
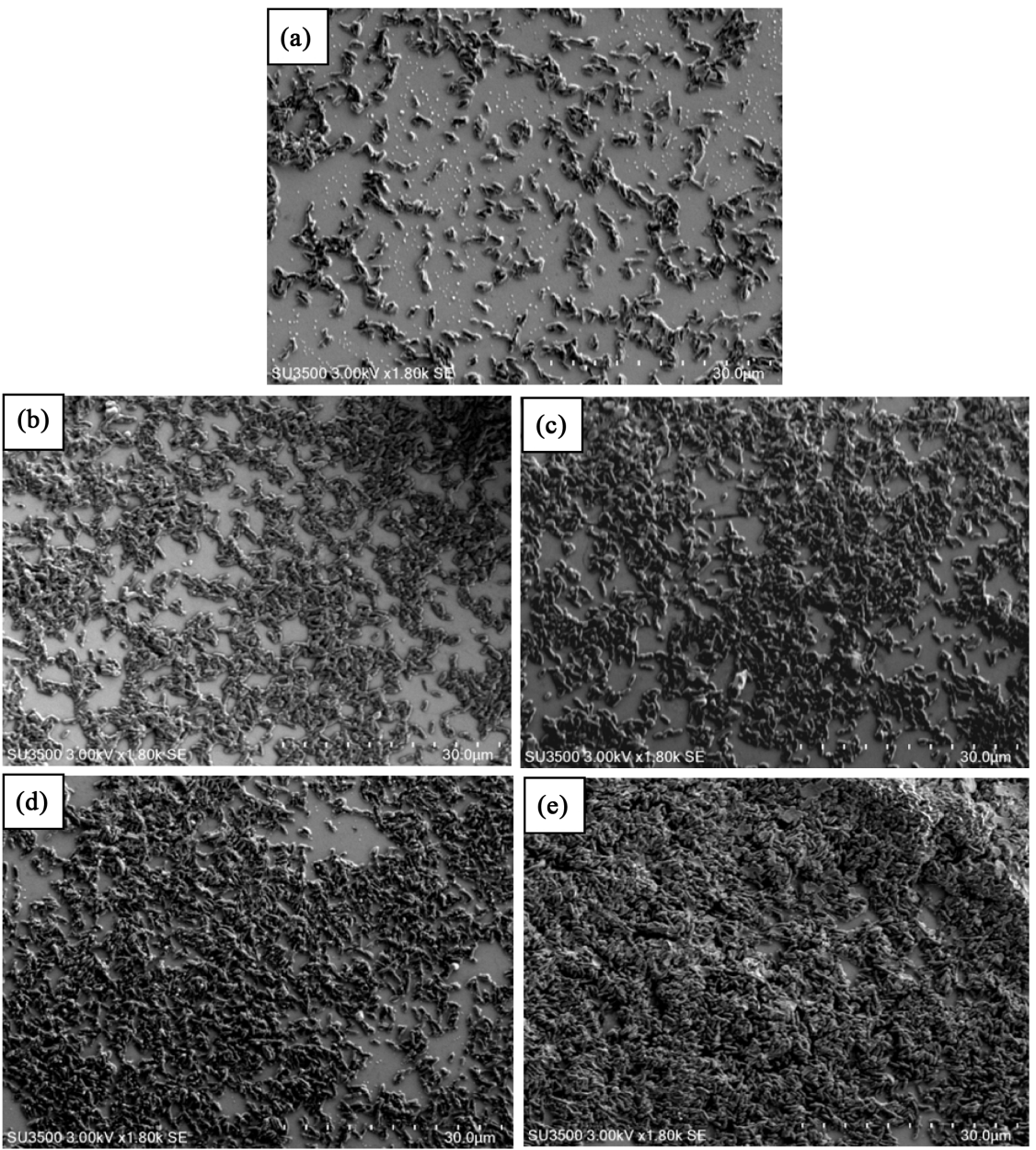

Figure 3. SEM of ITO electrode after an experiment for $S$. oneidensis MR-1. (a) at control $\left(\mathrm{TSB}+\right.$ Bacteria) and ((b), $\mathrm{Mg}^{2+} ;(\mathrm{c}), \mathrm{Cd}^{2+} ;(\mathrm{d}), \mathrm{Pb}^{2+}$; and (e), $\left.\mathrm{Ca}^{2+}\right)$ at $800 \mu \mathrm{M}$ concentrations. 


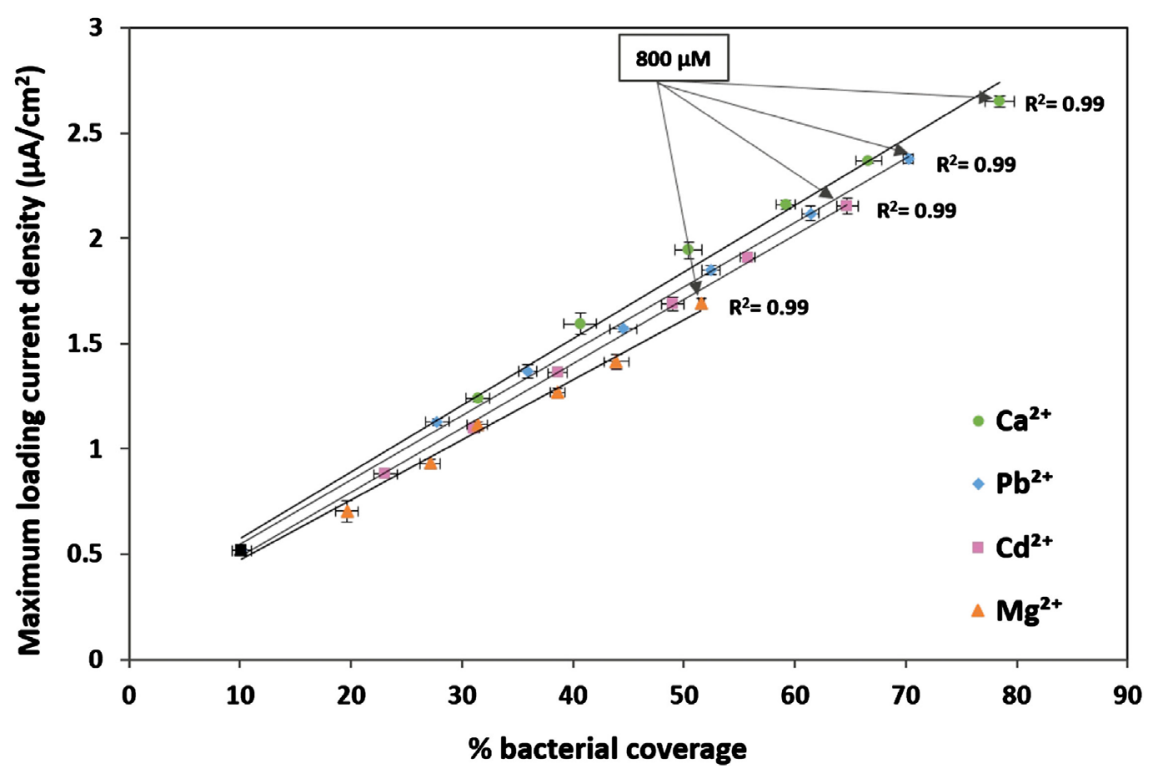

Figure 4. Maximum loading current density vs. percentage of $S$. oneidensis MR-1 coverage at control (TSB + Bacteria) and $\mathrm{Mg}^{2}, \mathrm{Cd}^{2+}, \mathrm{Pb}^{2+}$, and $\mathrm{Ca}^{2+}$ metal ion concentrations.

shows the average of triplicate maximum loading current density vs \% bacterial coverages. The relationship between maximum loading current density and \% bacterial coverages increases linearly $\left(\mathrm{R}^{2}=0.99\right)$. Once attached, at the same $\%$ coverage, the same maximum loading current density is observed between all metal ions. The effect is not metal ion-specific. $F$ test values are larger than 0.05 showing that this relationship. The metal ions, however, also show a specific effect on loading current. The maximum loading currents obtained (for coverages at $800 \mu \mathrm{M})$ for $\mathrm{Mg}^{2+}, \mathrm{Cd}^{2+}, \mathrm{Pb}^{2+}$, and $\mathrm{Ca}^{2+}$ were $2.25,3.13,3.58$, and 4.09 times higher than that of the control. F tests show that these values were significantly different.

A second set of electrochemical data belongs to cyclic voltammetry obtained after electrode loading at $+0.2 \mathrm{~V}$ vs $\mathrm{Ag} / \mathrm{AgCl}$ for two hours. The first of $6 \mathrm{CVs}$ are shown in Figure 5. The TSB only and metal ion blanks show no discernible peaks, as expected. It is observed that the reduction peak current is increased over the control when $\mathrm{Mg}^{2+}, \mathrm{Cd}^{2+}, \mathrm{Pb}^{2+}$, and $\mathrm{Ca}^{2+}$ are added. The shape of the $\mathrm{CV}$ suggests an adsorbed species [29] [37] [38]. The integrated peaks area under the reduction peak gives the amount of material that attached to the electrode surface.

$$
Q(C)=n F N
$$

where $(n)$ is the number of electrons transferred per molecule, $(F)$ is Faraday's constant $\left(96,485 \mathrm{C} \cdot \mathrm{mol}^{-1}\right)$, and $N$ is the amount of material electrolyzed in moles of either and or both the outer membrane cytochrome and the mediator flavin. Total $Q$ should be related to the percent coverage.

Consistent with Figure 4, the increase in the measured cathodic peak charge vs. percentage of $S$. oneidensis MR-1 coverage was linear $\left(\mathrm{R}^{2}=0.99\right)$ for each metal (Figure 6). There is a slight difference in linearity as measured by the 


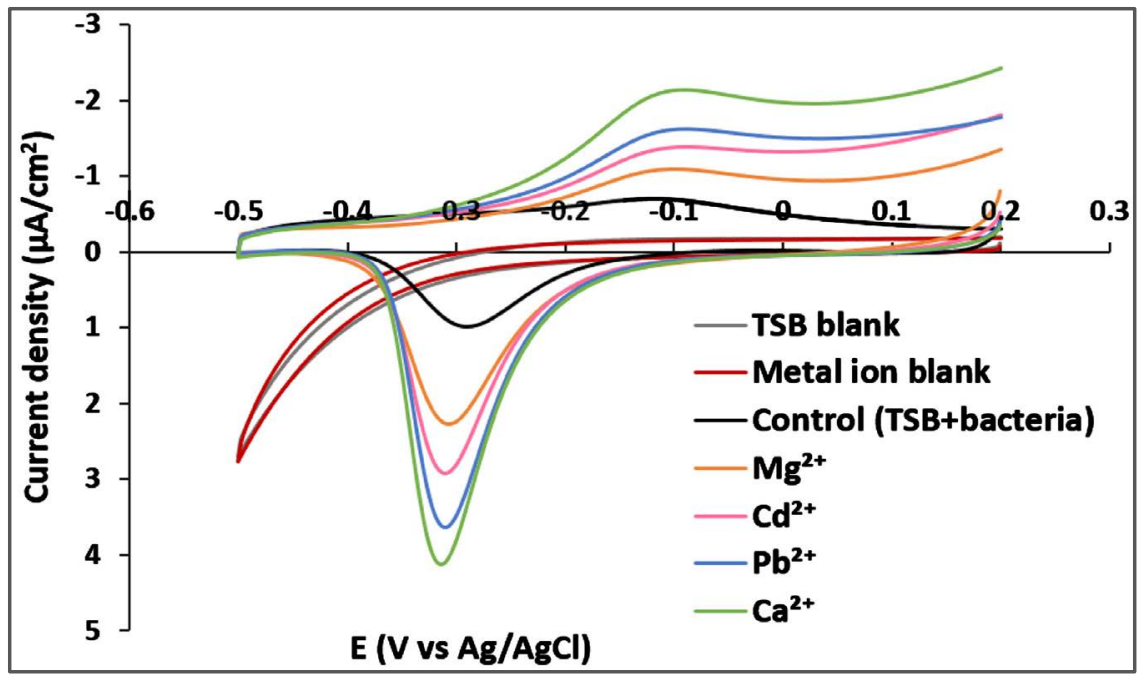

Figure 5. Cyclic voltammetry after electrode loading at $+0.2 \mathrm{~V}$ vs $\mathrm{Ag} / \mathrm{AgCl}$ for two-hours of $S$. oneidensis MR-1. The gray (TSB only) and red (TSB with metal ion added) lines are for blanks. The black line is for the control (TSB with bacteria). The orange, pink, blue and green lines represent metal ion of $\mathrm{Mg}^{2+}, \mathrm{Cd}^{2+}, \mathrm{Pb}^{2+}$, and $\mathrm{Ca}^{2+}$ concentrations at 800 $\mu \mathrm{M}$, respectively.

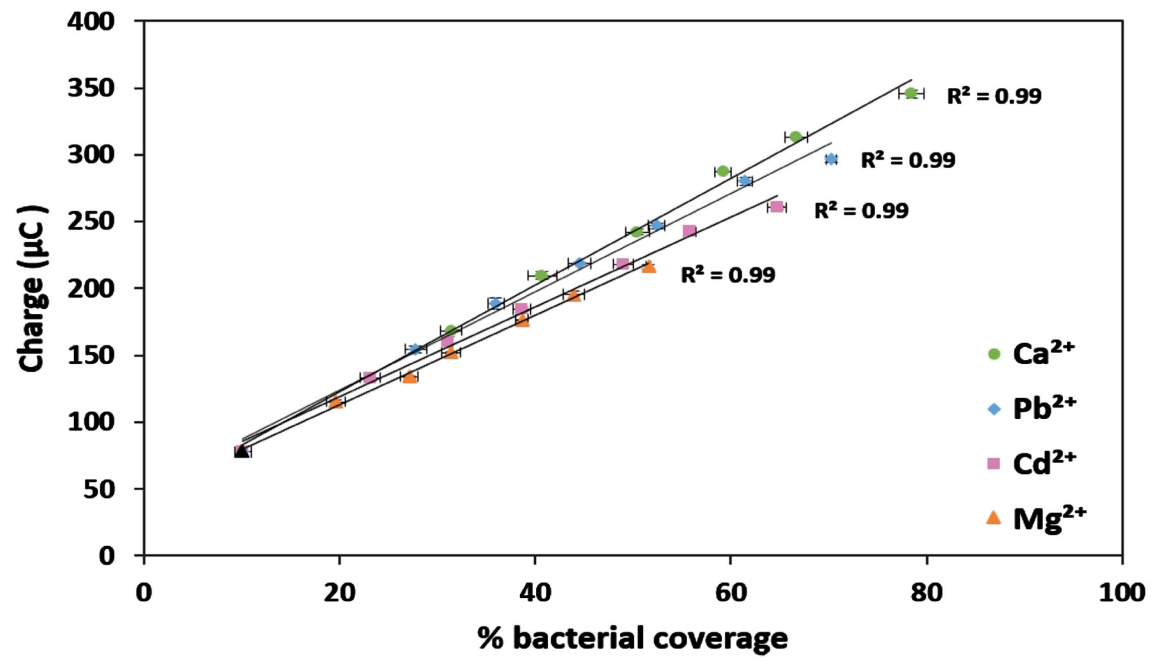

Figure 6. The cathodic peak charge vs. percentage of $S$. oneidensis MR-1 coverage at control (TSB + Bacteria) and $\mathrm{Mg}^{2+}, \mathrm{Cd}^{2+}, \mathrm{Pb}^{2+}$, and $\mathrm{Ca}^{2+}$ metal ion concentrations.

slope on charge and the type metal ion. $\mathrm{F}$ ratio values are less than 0.05 indicating that there is a difference in the slopes between charge and \% bacterial coverage. Above it was concluded when the cells are attached to the electrode surface, at a given total surface coverage, current output is non-specific between metal ions. Here it is noted that the ability to accept a charge (cathodic process) is slightly a metal ion-specific.

There are several hypotheses related to the increase in the metal ion concentration could increase bacterial attachment. Firstly, Shewanella surfaces are negatively charged at pH 7 [39] due to EPS structural anionic groups. Non-specific electrostatic forces may be applicable. Researchers have applied classical Derja- 
guin, Landau, Vervey, and Overbeek (DLVO) double layer theory to describe bacterial attachment to inorganic surfaces. The classical DLVO theory is described as the net interaction between a cell and a flat surface, which results from attractive van der Waals interactions and repulsive interactions between the electrical double layer of the cell and the substratum [40]. Choi et al. [26] studied the attachment and detachment of bacteria during various ionic strengths by using quartz sand surface. They found that increasing the ionic strength of the solution increased attachment. Similarly, Loosdrecht et al. [41] adhesion at polystyrene surfaces increased with increasing ionic strength of the electrolyte.

However, the theory does not adequately describe all of the observed behavior. Rijnaarts et al. [42] attempted to apply classical DLVO theory by controlling for the ionic strength and found only a moderate adherence to the theory. Rijnaarts et al. [42] study of bacterial adhesion on Teflon and glass surfaces hydrophobicity found different behavior at low ionic strength $(0.001 \mathrm{M})$ and high ionic strength $(0.1 \mathrm{M})$. At low ionic strength attachment was inhibited by DLVO-type electrostatic repulsion, but at high concentration attachment was controlled by steric interactions. We also found that classical DLVO theory failed to explain all the data in two ways. Ionic strength was held constant $(0.09 \mathrm{M})$, which should have resulted in no alteration of adhesion. DLVO theory would suggest that at similar concentrations there would be no effect in changing the cation species. Thus, like Rijnaarts classical DLVO theory was found insufficient to explain the results.

Secondly, DLVO theory can be altered by considering the hydrophobicity. Extracellular polymeric substance (EPS) is an important component in controlling the hydrophobicity of the bacterial cell surface. Tsuneda et al. [43] reported that if the amount of EPS is small, cell adhesion onto solid surfaces is inhibited by electrostatic interaction, and if the amount of EPS is large, cell adhesion is promoted by polymeric interaction.

An explanation for the results relates to metal ion binding within the EPS. Metal ions are known to bind to EPS [44] [45] and, therefore, likely affect the properties of the EPS. EPS on the bacteria may extend through the barrier into a region where attraction can dominate. As an example, Redman et al. [46] suggested that when the bacteria have attached from the pili or flagellum that can occur across the barrier when the microbe lies within the secondary minimum. Different adhesion effects result when the configuration of EPS is either tight or loose.

In addition to the interaction of metal ions with EPS Wei et al. [47] have found carboxyl and phosphate groups were mostly responsible for $\mathrm{Cd}^{2+}$ adsorption on bacterial cells and affect the affinity between the bacterial cells and metal ions. Dobrowolski et al. [48] found vibration band alterations associated with carboxylic acids and alcohols when $\mathrm{Cd}^{2+}$ and $\mathrm{Pb}^{2+}$ were bound extracellular substances obtained from bacteria. These effects are, in the literature, also predicted to be non-specific and related to trends in hydrated ionic radii, hydrated radii, and hydration energies [49] [50]. 
Thirdly, a supplemental explanation for the differences between metal ions is the impact of their water of hydration on binding to the EPS sites. As predicted, for a non-specific electrostatic mechanism, attachment increases with ionic radii, Figure 7. $\mathrm{Mg}^{2+}, \mathrm{Cd}^{2+}$, and $\mathrm{Ca}^{2+}$ follow the expected trend well. For these ions, bacterial coverage is linear with ionic radii $\left(\mathrm{R}^{2}=0.99\right)$. As expected, $\mathrm{Ca}^{2+}$ results in the highest current density. $\mathrm{Pb}^{2+}$ is out of sequence between $\mathrm{Mg}^{2+}, \mathrm{Cd}^{2+}$, and $\mathrm{Ca}^{2+}$. Inclusion of $\mathrm{Pb}^{2+}$ into the sequence resulted in a significantly poorer correlation between $\%$ bacterial coverage and ionic radii $\left(\mathrm{R}^{2}=0.79\right)$. This difference may be related to alterations in valence shell electrons. The structure of the hydrated $\mathrm{Pb}^{2+}$ ion is affected by the lone electron pair, which is giving complex hemi-directed in aqueous solution [51].

Finally, metal ions may affect the metabolism of the bacteria. $\mathrm{Cd}^{2+}$ is known to be far more toxic than $\mathrm{Pb}^{2+}$. As the minimal inhibitory concentration (MIC) is $0.5 \mathrm{~g} / \mathrm{cm}^{3}$ for $\mathrm{Cd}^{2+}$ compared to $5.0 \mathrm{~g} / \mathrm{cm}^{3}$ for $\mathrm{Pb}^{2+}$. The effect is suggested to be a metabolic one in $\mathrm{Cd}^{2+}$ where $\mathrm{Cd}^{2+}$ interferes with both $\mathrm{Ca}^{2+}$ and $\mathrm{Zn}^{2+}$ related sulfhydryl group [27]. In order to check metabolism, several experiments were performed.

First, the optical density (O.D.) was measured from the extracted volume of growth media in the electrochemical cell (Figure 8). There is no observed difference in the optical density from the beginning to the end of the experiment between metal ions. This suggests that there is no toxic effect inhibiting microbial growth in solution. This is despite the difference in minimum inhibitory concentration (MIC) for the metal ions.

Second, HPLC was utilized to measure the glucose consumed during the electrochemical experiment (Figure 8). Glucose consumption was dependent on the type of metal ions in the cultures. Glucose concentrations found in solutions of $800 \mu \mathrm{M} \mathrm{Mg}^{2+}, \mathrm{Cd}^{2+}, \mathrm{Pb}^{2+}$, and $\mathrm{Ca}^{2+}$, are $0.45,0.67,0.85$, and $1.53 \mathrm{~g} / \mathrm{l}$, respectively. These values are much higher than that consumed by the control $0.14 \mathrm{~g} / \mathrm{l}$.

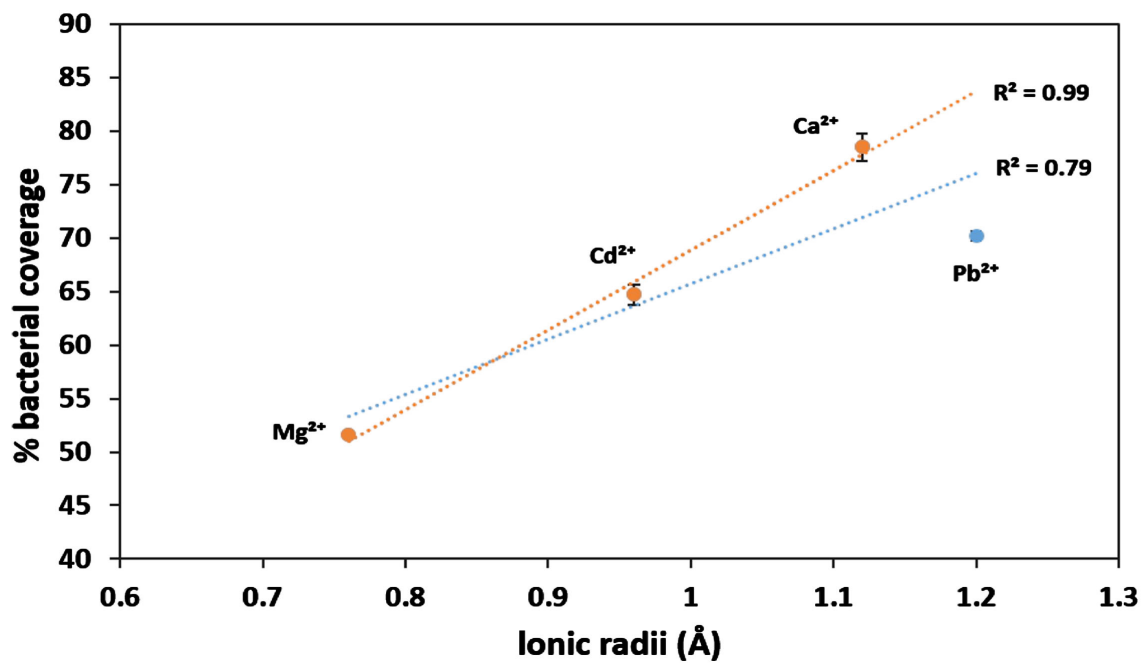

Figure 7. \% bacterial electrode coverage vs ionic radii $(\AA)$ of $\mathrm{Mg}^{2+}, \mathrm{Cd}^{2+}, \mathrm{Pb}^{2+}$, and $\mathrm{Ca}^{2+}$ metal ions. 


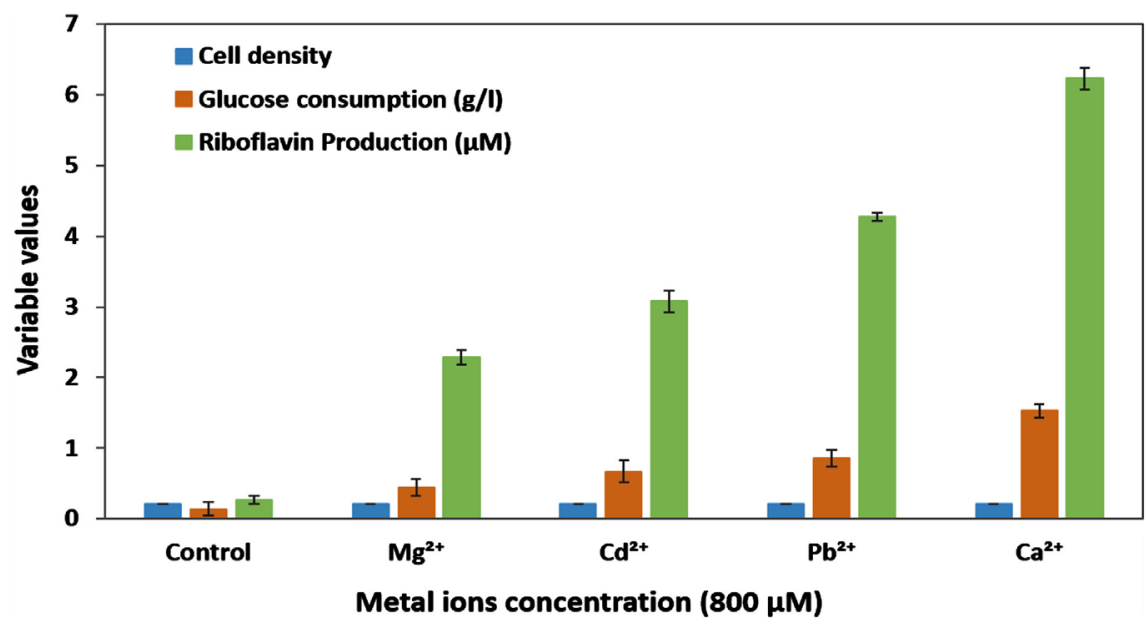

Figure 8. Cell density on exit of electrochemical cell (blue), glucose consumption (orange), and riboflavin production (green) vs. control (TSB+Bacteria) and $\mathrm{Mg}^{2+}, \mathrm{Cd}^{2+}$, $\mathrm{Pb}^{2+}$, and $\mathrm{Ca}^{2+}$ metal ion concentrations at $800 \mu \mathrm{M}$ for $S$. oneidensis MR-1.

Fitzgerald et al. [14] found that the lactate consumed was independent of the concentration of $\mathrm{CaCl}_{2}$ in the medium.

Third, riboflavin production was monitored. Riboflavin has been identified as an indirect extracellular electron transfer (EET) mediator, acting as an electron shuttle for the EET of $S$. oneidensis MR-1 in MFCs [10] [52]. There is a difference between metal ions which may be metabolitic [14] [53]. Xu et al. [11] found that the riboflavin was increased with $\mathrm{Cu}^{2+}$ and $\mathrm{Cd}^{2+}(1.78$ and $1.73 \mu \mathrm{M})$ compared to the control $(1.46 \mu \mathrm{M})$. The concentration of riboflavin was measured by HPLC (Figure 8). Riboflavin concentrations found in solutions of $800 \mu \mathrm{M}$ for $\mathrm{Mg}^{2+}, \mathrm{Cd}^{2+}, \mathrm{Pb}^{2+}$, and $\mathrm{Ca}^{2+}$ were $2.28,3.08,4.27$, and $6.23 \mu \mathrm{M}$, respectively. These values are much higher than that produced by the control, $0.26 \mu \mathrm{M}$. As riboflavin is a mediator for electron transfer, increased riboflavin product should increase electrochemical activity of the bacteria. The trends were consistent with all of the electrochemical trends observed above. Both sets of experiments indicate that glucose (consumed) and riboflavin (produced) follow the same trends in the electrochemical behavior shown above.

The results implied that metal ions $\mathrm{Mg}^{2+}, \mathrm{Cd}^{2+}, \mathrm{Pb}^{2+}$, and $\mathrm{Ca}^{2+}$ enhanced bacteria attachment to the electrode surface and that might, in part, contribute to current output improvement. There are other factors related to the current output. For example, cellular metabolism and activity of electron transfer chain (e.g., c-type cytochrome). These factors might be influenced by metal ions $\mathrm{Mg}^{2+}$, $\mathrm{Cd}^{2+}, \mathrm{Pb}^{2+}$, and $\mathrm{Ca}^{2+}$ and might play a role in current output improvement.

\section{Conclusion}

This study shows that the current output generation from Shewanella. oneidensis MR-1 is affected by the addition of metal ions. Heavy metals ions are expected to have a toxic effect on bacterial growth. In this study, heavy metals had no effect in optical density of extracted solutions indicating the bacterial growth 
in the solution was unaffected. $\mathrm{Mg}^{2+}, \mathrm{Cd}^{2+}, \mathrm{Pb}^{2+}$, and $\mathrm{Ca}^{2+}$ significantly increased current output compared to that of the control. Further analyses indicated that metal ions increased anodic biofilm formation. Once attached, a linear relationship was found between the \% bacterial coverage and electrochemical performance. This may be related to alterations in the EPS structure, as observed elsewhere. These results suggest avenues of research in the improvement of performance and operation of MFCs.

\section{Acknowledgements}

The author sincerely acknowledges scholarship from Al-Baha University for the doctoral program. The author would like to thank the Department of Chemistry at Northeastern Illinois University for providing the HPLC instrument for sample analysis. This research utilized a scanning electron microscope, which was funded by the NSF, Major Research Instrumentation (MRI) Program via Award No. 1726994.

\section{Conflicts of Interest}

The authors declare no conflicts of interest relevant to this article.

\section{References}

[1] Santoro, C., Arbizzani, C., Erable, B. and Ieropoulos, I. (2017) Microbial Fuel Cells: From Fundamentals to Applications. A Review. Journal of Power Sources, 356, 225-244. https://doi.org/10.1016/j.jpowsour.2017.03.109

[2] Slate, A.J., Whitehead, K.A., Brownson, D.A. and Banks, C.E. (2019) Microbial Fuel Cells: An Overview of Current Technology. Renewable and Sustainable Energy Review, 101, 60-81. https://doi.org/10.1016/j.rser.2018.09.044

[3] Kumar, R., Singh, L., Zularisam, A. and Hai, F.I. (2018) Microbial Fuel Cell Is Emerging as a Versatile Technology: A Review on Its Possible Applications, Challenges and Strategies to Improve the Performances. International Journal of Energy Research, 42, 369-394. https://doi.org/10.1002/er.3780

[4] Miyahara, M., Kouzuma, A. and Watanabe, K. (2015) Effects of NaCl Concentration on Anode Microbes in Microbial Fuel Cells. AMB Express, 5, 34. https://doi.org/10.1186/s13568-015-0123-6

[5] Kane, A.L., Brutinel, E.D., Joo, H., Maysonet, R., VanDrisse, C.M., Kotloski, N.J. and Gralnick, J.A. (2016) Formate Metabolism in Shewanella oneidensis Generates Proton Motive Force and Prevents Growth without an Electron Acceptor. Journal of Bacteriology, 198, 1337-1346. https://doi.org/10.1128/JB.00927-15

[6] Kim, H.J., Park, H.S., Hyun, M.S., Chang, I.S., Kim, M. and Kim, B.H. (2002) A Mediator-Less Microbial Fuel Cell Using a Metal Reducing Bacterium, Shewanella putrefaciens. Enzyme and Microbial Technology, 30, 145-152. https://doi.org/10.1016/S0141-0229(01)00478-1

[7] Pirbadian, S., Barchinger, S.E., Leung, K.M., Byun, H.S., Jangir, Y., Bouhenni, R.A., Reed, S.B., Romine, M.F., Saffarini, D.A. and Shi, L. (2014) Shewanella oneidensis MR-1 Nanowires Are Outer Membrane and Periplasmic Extensions of the Extracellular Electron Transport Components. Proceedings of the National Academy of Sciences of the United States of America, 111, 12883-12888. 
https://doi.org/10.1073/pnas.1410551111

[8] Carmona-Martinez, A.A., Harnisch, F., Fitzgerald, L.A., Biffinger, J.C., Ringeisen, B.R. and Schröder, U. (2011) Cyclic Voltammetric Analysis of the Electron Transfer of Shewanella oneidensis MR-1 and Nanofilament and Cytochrome Knock-out Mutants. Bioelectrochemistry, 81, 74-80. https://doi.org/10.1016/j.bioelechem.2011.02.006

[9] Okamoto, A., Nakamura, R., Nealson, K.H. and Hashimoto, K. (2014) Bound Flavin Model Suggests Similar Electron-Transfer Mechanisms in Shewanella and Geobacter. ChemElectroChem, 1, 1808-1812.

[10] Marsili, E., Baron, D.B., Shikhare, I.D., Coursolle, D., Gralnick, J.A. and Bond, D.R. (2008) Shewanella Secretes Flavins that Mediate Extracellular Electron Transfer. Proceedings of the National Academy of Science of the United States of America, 105, 3968-3973. https://doi.org/10.1073/pnas.0710525105

[11] Xu, Y.-S., Zheng, T., Yong, X.-Y., Zhai, D.-D., Si, R.-W., Li, B., Yu, Y.-Y. and Yong, Y.-C. (2016) Trace Heavy Metal Ions Promoted Extracellular Electron Transfer and Power Generation by Shewanella in Microbial Fuel Cells. Bioresource Technology, 211, 542-547. https://doi.org/10.1016/j.biortech.2016.03.144

[12] Wu, D., Xing, D., Lu, L., Wei, M., Liu, B. and Ren, N. (2013) Ferric Iron Enhances Electricity Generation by Shewanella oneidensis MR-1 in MFCs. Bioresource Technology, 135, 630-634. https://doi.org/10.1016/j.biortech.2012.09.106

[13] Kim, J.R., Min, B. and Logan, B.E. (2005) Evaluation of Procedures to Acclimate a Microbial Fuel Cell for Electricity Production. Applied Microbiology and Biotechnology, 68, 23-30. https://doi.org/10.1007/s00253-004-1845-6

[14] Fitzgerald, L.A., Petersen, E.R., Gross, B.J., Soto, C.M., Ringeisen, B.R., El-Naggar, M.Y. and Biffinger, J.C. (2012) Aggrandizing Power Output from Shewanella oneidensis MR-1 Microbial Fuel Cells Using Calcium Chloride. Biosensors and Bioelectronics, 31, 492-498. https://doi.org/10.1016/j.bios.2011.11.024

[15] Lu, Z., Chang, D., Ma, J., Huang, G., Cai, L. and Zhang, L. (2015) Behavior of Metal Ions in Bioelectrochemical Systems: A Review. Journal of Power Sources, 275, 243-260. https://doi.org/10.1016/j.jpowsour.2014.10.168

[16] Liu, H., Cheng, S. and Logan, B.E. (2005) Power Generation in Fed-Batch Microbial Fuel Cells as a Function of Ionic Strength, Temperature and Reactor Configuration. Environmental Science \& Technology, 39, 5488-5493. https://doi.org/10.1021/es050316c

[17] Mohan, Y. and Das, D. (2009) Effect of Ionic Strength, Cation Exchanger and Inoculum Age on the Performance of Microbial Fuel Cells. International Journal of Hydrogen Energy, 34, 7542-7546. https://doi.org/10.1016/j.ijhydene.2009.05.101

[18] Myers, C.R. and Myers, J.M. (1992) Localization of Cytochromes to the Outer Membrane of Anaerobically Grown Shewanella putrefaciens MR-1. Journal of Bacteriology, 174, 3429-3438. https://doi.org/10.1128/jb.174.11.3429-3438.1992

[19] Bazaka, K., Crawford, R.J., Nazarenko, E.L. and Ivanova, E.P. (2011) Bacterial Extracellular Polysaccharides. In: Linke, D. and Goldman, A., Eds., Bacterial Adhesion, Springer, Dordrecht, 213-226. https://doi.org/10.1007/978-94-007-0940-9_13

[20] Clifton, L.A., Skoda, M.W., Le Brun, A.P., Ciesielski, F., Kuzmenko, I., Holt, S.A. and Lakey, J.H. (2014) Effect of Divalent Cation Removal on the Structure of Gram-Negative Bacterial outer Membrane Models. Langmuir, 31, 404-412. https://doi.org/10.1021/la504407v

[21] Patrauchan, M.A., Sarkisova, S., Sauer, K. and Franklin, M.J. (2005) Calcium Influ- 
ences Cellular and Extracellular Product Formation during Biofilm-Associated Growth of a Marine Pseudoalteromonas sp. Microbiology, 151, 2885-2897. https://doi.org/10.1099/mic.0.28041-0

[22] Kierek, K. and Watnick, P.I. (2003) The Vibrio Cholerae O139 O-Antigen Polysaccharide Is Essential for $\mathrm{Ca}^{2+}$ Dependent Biofilm Development in Sea Water. Proceedings of the National Academy of Sciences of the United States of America, 100, 14357-14362. https://doi.org/10.1073/pnas.2334614100

[23] Guvensen, N.C., Demir, S. and Ozdemir, G. (2012) Effects of Magnesium and Calcium Cations on Biofilm Formation by Sphingomonas paucimobilis from an Industrial Environment. Fresenius Environmental Bulletin, 21, 3685-3692.

[24] Zhang, H. and Olson, M.S. (2012) Effect of Heavy Metals on Bacterial Attachment in Soils. Journal of Environmental Engineering, 138, 1106-1113. https://doi.org/10.1061/(ASCE)EE.1943-7870.0000573

[25] Sheng, X., Ting, Y.P. and Pehkonen, S.O. (2008) The Influence of Ionic Strength, Nutrients and $\mathrm{pH}$ on Bacterial Adhesion to Metals. Journal of Colloid and Interface Science, 321, 256-264. https://doi.org/10.1016/j.jcis.2008.02.038

[26] Choi, N.C., Choi, J.W., Kwon, K.S., Lee, S.G. and Lee, S. (2017) Quantifying Bacterial Attachment and Detachment Using Leaching Solutions of Various Ionic Strengths after Bacterial Pulse. AMB Express, 7, 38. https://doi.org/10.1186/s13568-017-0340-2

[27] Nies, D.H. (1999) Microbial Heavy-Metal Resistance. Applied Microbiology and Biotechnology, 51, 730-750. https://doi.org/10.1007/s002530051457

[28] Sharma, R.K. and Agrawal, M. (2005) Biological Effects of Heavy Metals: An Overview. Journal of Environmental Biology, 26, 301-313.

[29] Muscolino, J. (2016) Building and Optimizing a Spectroelectrochemical System for the Study of Shewanella Putrefaciens.

[30] Bose, S., Hochella Jr., M.F., Gorby, Y.A., Kennedy, D.W., McCready, D.E., Madden, A.S. and Lower, B.H. (2009) Bioreduction of Hematite Nanoparticles by the Dissimilatory Iron Reducing Bacterium Shewanella oneidensis MR-1. Geochimica et Cosmochimica Acta, 73, 962-976. https://doi.org/10.1016/j.gca.2008.11.031

[31] Fitch, A., Agyeman, A., Wagdy, A. and Terranova, Z. (2010) Electroactive Planar Waveguide Studies of Ru (bpy) ${ }_{3}^{2+}$ Intercalated in a Thin Clay Film: I. Transport and Electrochemical Phenomena. Langmuir, 27, 452-460. https://doi.org/10.1021/la102482c

[32] Zhang, J., Zhang, Q., Wang, J., Shi, X. and Zhang, Z. (2009) Analysis of the Monosaccharide Composition of Fucoidan by Precolumn Derivation HPLC. Chinese Journal of Oceanology and Limnology, 27, 578-582. https://doi.org/10.1007/s00343-009-9205-0

[33] Ye, Y., Ling, N., Jiao, R., Wu, Q., Han, Y. and Gao, J. (2015) Effects of $\mathrm{Ca}^{2+}$ and $\mathrm{Mg}^{2+}$ on the Biofilm Formation of Cronobacter Sakazakii Strains from Powdered Infant Formula. Journal of Food Safety, 35, 416-421.

https://doi.org/10.1111/jfs.12190

[34] Liu, G., Yates, M.D., Cheng, S., Call, D.F., Sun, D. and Logan, B.E. (2011) Examination of Microbial Fuel Cell Start-up Times with Domestic Wastewater and Additional Amendments. Bioresource Technology, 102, 7301-7306.

https://doi.org/10.1016/j.biortech.2011.04.087

[35] Zhang, X., Liang, P., Shi, J., Wei, J. and Huang, X. (2013) Using a Glass Fiber Separator in a Single-Chamber Air-Cathode Microbial Fuel Cell Shortens Start-up Time 
and Improves Anode Performance at Ambient and Mesophilic Temperatures. Bioresource Technology, 130, 529-535. https://doi.org/10.1016/j.biortech.2012.12.091

[36] Zou, L., Wu, X., Huang, Y., Ni, H. and Long, Z.E. (2018) Promoting Shewanella Bidirectional Extracellular Electron Transfer for Bioelectrocatalysis by Electropolymerized Riboflavin Interface on Carbon Electrode. Frontiers in Microbiology, 9, 3293. https://doi.org/10.3389/fmicb.2018.03293

[37] Steentjes, T., Jonkheijm, P. and Huskens, J. (2017) Electron Transfer Processes in Ferrocene-Modified Poly (Ethylene Glycol) Monolayers on Electrodes. Langmuir, 33, 11878-11883. https://doi.org/10.1021/acs.langmuir.7b02160

[38] Laviron, E. (1979) General Expression of the Linear Potential Sweep Voltammogram in the Case of Diffusionless Electrochemical Systems. Journal of Electroanalytical Chemistry and Interfacial Electrochemistry, 101, 19-28.

https://doi.org/10.1016/S0022-0728(79)80075-3

[39] Sokolov, I., Smith, D., Henderson, G., Gorby, Y. and Ferris, F. (2001) Cell Surface Electrochemical Heterogeneity of the Fe (III)-Reducing Bacteria Shewanella putrefaciens. Environmental Science \& Technology, 35, 341-347.

https://doi.org/10.1021/es001258s

[40] Hermansson, M. (1999) The DLVO Theory in Microbial Adhesion. Colloids and Surfaces B: Biointerfaces, 14, 105-119. https://doi.org/10.1016/S0927-7765(99)00029-6

[41] van Loosdrecht, M.C., Lyklema, J., Norde, W. and Zehnder, A.J. (1989) Bacterial Adhesion: A Physicochemical Approach. Microbial Ecology, 17, 1-15. https://doi.org/10.1007/BF02025589

[42] Rijnaarts, H.H., Norde, W., Lyklema, J. and Zehnder, A.J. (1999) DLVO and Steric Contributions to Bacterial Deposition in Media of Different Ionic Strengths. Colloids and Surfaces B: Biointerfaces, 14, 179-195. https://doi.org/10.1016/S0927-7765(99)00035-1

[43] Tsuneda, S., Aikawa, H., Hayashi, H., Yuasa, A. and Hirata, A. (2003) Extracellular Polymeric Substances Responsible for Bacterial Adhesion onto Solid Surface. FEMS Microbiology Letters, 223, 287-292. https://doi.org/10.1016/S0378-1097(03)00399-9

[44] Beveridge, T. and Fyfe, W. (1985) Metal Fixation by Bacterial Cell Walls. Canadian Journal of Earth Sciences, 22, 1893-1898. https://doi.org/10.1139/e85-204

[45] Guiné, V., Spadini, L., Sarret, G., Muris, M., Delolme, C., Gaudet, J.P. and Martins, J. (2006) Zinc Sorption to Three Gram-Negative Bacteria: Combined Titration, Modeling and EXAFS Study. Environmental Science \& Technology, 40, 1806-1813. https://doi.org/10.1021/es0509811

[46] Redman, J.A., Walker, S.L. and Elimelech, M. (2004) Bacterial Adhesion and Transport in Porous Media: Role of the Secondary Energy Minimum. Environmental Science \& Technology, 38, 1777-1785. https://doi.org/10.1021/es0348871

[47] Wei, X., Fang, L., Cai, P., Huang, Q., Chen, H., Liang, W. and Rong, X. (2011) Influence of Extracellular Polymeric Substances (EPS) on Cd Adsorption by Bacteria. Environmental Pollution, 159, 1369-1374. https://doi.org/10.1016/j.envpol.2011.01.006

[48] Dobrowolski, R., Szcześ, A., Czemierska, M. and Jarosz-Wikołazka, A. (2017) Studies of Cadmium (II), Lead (II), Nickel (II), Cobalt (II) and Chromium (VI) Sorption on Extracellular Polymeric Substances Produced by Rhodococcus opacus and Rhodococcus rhodochrous. Bioresource Technology, 225, 113-120. https://doi.org/10.1016/j.biortech.2016.11.040

[49] Rivera-Utrilla, J., Bautista-Toledo, I., Ferro-García, M. A. and Moreno-Castilla, C. 
(2001) Activated Carbon Surface Modifications by Adsorption of Bacteria and Their Effect on Aqueous Lead Adsorption. Journal of Chemical Technology \& Biotechnology, 76, 1209-1215. https://doi.org/10.1002/jctb.506

[50] Ferris, F.G. and Beveridge, T. (1986) Physicochemical Roles of Soluble Metal Cations in the Outer Membrane of Escherichia coli K-12. Canadian Journal of Microbiology, 32, 594-601. https://doi.org/10.1139/m86-110

[51] Persson, I. (2010) Hydrated Metal Ions in Aqueous Solution: How Regular Are Their Structures? Pure and Applied Chemistry, 82, 1901-1917. https://doi.org/10.1351/PAC-CON-09-10-22

[52] Yong, Y.C., Cai, Z., Yu, Y.Y., Chen, P., Jiang, R., Cao, B., Sun, J.Z., Wang, J.Y. and Song, H. (2013) Increase of Riboflavin Biosynthesis Underlies Enhancement of Extracellular Electron Transfer of Shewanella in Alkaline Microbial Fuel Cells. Bioresource Technology, 130, 763-768. https://doi.org/10.1016/j.biortech.2012.11.145

[53] Fitzgerald, L.A., Petersen, E.R., Leary, D.H., Nadeau, L.J., Soto, C.M., Ray, R.I., Little, B.J., Ringeisen, B.R., Johnson, G.R. and Vora, G.J. (2013) Shewanella frigidimarina Microbial Fuel Cells and the Influence of Divalent Cations on Current Output. Biosensors and Bioelectronics, 40, 102-109.

https://doi.org/10.1016/j.bios.2012.06.039 